\title{
Representasi Nilai Dakwah dalam Iklan Susu Frisian Flag Gold Edisi Ramadhan 2017
}

\section{Yera Yulista}

IAIN Syaikh Abdurrahman Siddik Bangka Belitung, Indonesia yerabelajar@gmail.com

\begin{abstract}
Abstrak: $\quad$ Komunikasi adalah cara menyampaikan ide, konsep dari pikiran seseorang kepada orang lain untuk menghasilkan pengertian yang sama. Bentuk nyata dari penuangan ide itu sendiri dimunculkan lewat simbol-simbol (tanda) verbal atau non verbal sehingga dapat diterjemahkan maknanya oleh penerima pesan. Begitupun juga dengan tayangan iklan komersil yang merupakan bentuk komunikasi hasil dari konsep pemikiran pengiklan untuk disampaikan kepada penonton sehingga menimbulkan dampak yang diinginkan pengiklan yakni selain produk yang ditawarkan menjadi dikenal namun dapat juga menarik pembelian produk itu sendiri. Agar pembelian produk dapat berhasil maka pengiklan harus merancang pesan dalam iklan seefektif mungkin dengan menuangkan konsep iklan yang kreatif sehingga memiliki posisi tawar diantara sekian banyak pesaing lainnya dengan produk yang sama misalkan dengan cara menampilkan keunggulan produk yang memiliki manfaat di dalam kehidupan manusia, salah satunya lewat Iklan Susu Frisian Flag Gold. Iklan yang ditayangkan pada 2017 ini mencoba mengemas kelebihan produk lewat settingan waktu bulan ramadhan yang sarat dengan nilai dakwah. Hal ini yang menarik perhatian peneliti untuk melihat Representasi Nilai Dakwah dalam Iklan Susu Frisian Flag Gold Edisi Ramadhan 2017 melalui pendekatan semiotika.
\end{abstract}

Kata Kunci; Iklan, Simbol, dan Semiotika. 


\section{A. Pendahuluan}

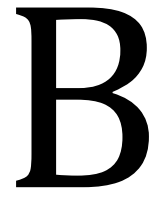

anyak strategi yang dapat dilakukan oleh produsen untuk mengenalkan produknya sehingga menjadi minat beli bagi calon konsumen. Salah satunya melalui cara beriklan. Beriklan sebenarnya adalah bentuk dari aktivitas komunikasi yakni ada sejumlah pesan berupa tanda-tanda yang memiliki makna yang ingin disampaikan untuk dipahami penonton sehingga memiliki daya tarik untuk menonton iklan tersebut dan pada akhirnya berdampak pada membeli produk yang ditawarkan. Produk yang diiklankan jelas harus meyakinkan calon konsumen bahwa produk yang ditawar memiliki keunggulan sehingga memiliki nilai atau manfaat bagi yang akan menggunakannya.

Berkaitan dengan hal diatas daya kreatifitas para pengiklan ditantang yakni bagaimana iklan yang terdiri dari tanda-tanda verbal (lisan, tulisan) ataupun nonverbal harus diramu sedemikian rupa agar dapat menarik, menimbulkan kesan dan bisa mempengaruhi penonton untuk membeli produk. Unsur dari pesan iklan tersebut harus dirancang, harus mengena para penonton yang menerima pesan sehingga penonton sebagai calon pangsa pasar memiliki persepsi yang menarik tentang produk yang ditawarkan. Oleh sebab itu, merancang pesan dalam iklan sama halnya untuk mewujudkan tujuan komunikasi itu sendiri, yaitu berupa pemaknaan yang sama antara pengiklan dan penonton (calon konsumen) dari pesan yang disuguhkan atau dengan kata lain menghasilkan komunikasi yang efektif. Menurut Berelson dan Steiner, komunikasi adalah pengoperan informasi, gagasan, emosi, keterampilan dan lain-lain dengan menggunakan simbol, gambar, kata-kata. ${ }^{1}$

Komunikasi yang efektif salah satunya dapat diwujudkan dengan mengetahui karakteristik pesan sehingga dapat mengemas pesan iklan menjadi efektif yakni melalui tiga tahap awareness, interest dan loyalty. Berikut pemaparannya: Pertama, Awareness berupa perubahan pengetahuan melalui branding (pengenalan merek), kemasan (bentuk dan warna), figur (artis cantik dan tampan, anak-anak yang lucu, ibu yang simpatik); Kedua, Interest berupa perubahan sikap melalui branding (penguatan merek), emosional (figur atau perilaku), kelebihan produk (fungsi dan manfaat produk) dan Ketiga Loyalty

1 Enjang AS, Komunikasi Konseling Dari Wawancara, Seni Mendengar, sampai Soal Kepribadian (Bandung: Nuansa, 2009), p. 15. 
berupa perubahan perilaku terdiri dari emotional brand (kecintaan terhadap brand), akibat penggunaan produk lain dan pendiskreditan produk lain. ${ }^{2}$

Lebih jelas lagi apabila produsen ingin menarik perhatian calon konsumen melalui iklan maka penyusunan karakteristik pesan harus dipertimbangkan agar betul-betul mengena minat mereka untuk membeli produk. Seperti yang kita ketahui bahwa iklan adalah bagian dari unsur pemasaran. Dalam mengembangkan pemasaran yang efektif maka selain unsur product, price, place yang menjadi perhatian maka unsur promotion juga harus dipertimbangkan. Bergabungnya semua elemen promosi menjadi istilah Intergrated Marketing Communications atau yang lebih populer penyebutaannya adalah IMC, iklan menjadi salah satu bagian dari elemen IMC tersebut.

Iklan yang dibuat tidak lepas dari konsep perancang iklan, bagaimana harus merancang iklan, membuat jalan cerita iklan agar menimbulkan suatu kesan positif bagi audiens yang menonton iklan tersebut. Begitupun juga dengan iklan Susu Frisian Flag Gold. Iklan yang berdurasi 30 detik ini juga menampilkan tanda-tanda (pesan) yang sarat dengan nilai promosi untuk mengenalkan produk dan ada sisi lain yang menarik yakni ada suatu jalan cerita dari iklan tersebut yang mengaitkan fungsi produk sehingga membuat peneliti lebih tertarik untuk mengkaji iklan tersebut. Pakar Komunikasi Little John mengatakan dalam teorinya bahwa tanda-tanda (sign) adalah basis atau dasar dari seluruh komunikasi. Manusia dengan perantaraan tanda-tanda dapat melakukan komunikasi dengan sesamanya dan banyak hal yang bisa dikomunikasikan di dunia ini. ${ }^{3}$

Sisi menarik bagi peneliti adalah peneliti melihat ada kepiawaian seorang perancang iklan dalam mengenalkan produk yang dikaitkan dengan aktivitas sekelompok masyarakat dalam hal ini kelompok umat Islam yang sedang melaksanakan ibadah puasa. Peneliti melihat ada ide disana, kepintaran mengaitkan produk yang ditawarkan dengan jalan cerita yang menggambarkan kehidupan sehari-hari sehingga pada akhirnya memunculkan kesan bahwa produk yang ditawarkan memiliki manfaat, dapat menjadi pilihan utama untuk dikonsumsi bagi kaum muslimin yang sedang berpuasa dan tentunya ada sejumlah nilai-nilai dakwah yang terkandung dalam iklan tersebut, ini yang menarik bagi peneliti.

\footnotetext{
${ }^{2}$ John E. Kennedy and R.Dermawan Soemanagara, Marketing Communication: Taktik \& Strategi (Jakarta: PT. Bhuana Ilmu Populer, 2006), p. 61.

${ }^{3}$ Indiwan Seto Wahyu Wibowo, Semiotika Komunikasi Aplikasi Praktis bagi Penelitian dan Skripsi Komunikasi (Jakarta: Mitra Wacana Media, 2011), p. 6.
} 
Berdakwah pada dasarnya adalah menyeru, seperti yang dikuatkan oleh Syekh Ali Mahfudh, dakwah dalam pandangan Islam adalah mendorong manusia agar melakukan kebaikan dan menuruti petunjuk, menyeru mereka berbuat kebajikan dan melarang perbuatan mungkar, agar mereka mendapatkan kebahagiaan didunia dan di akhirat. ${ }^{4}$ Dakwah dalam pandangan luasnya tidak lah hanya identik dengan aktivitas berkomunikasi antara mubaligh dengan mad'u dari atas mimbar saja, namun aktivitas dakwah menurut pandangan peneliti dapat juga terkait dengan berbagai aktivitas jenis lainnya yang tentunya tetap dengan prinsip mengandung nilai dakwah dalam pandangan Islam.

Begitupun juga dengan iklan yang dimaksud oleh peneliti, beriklan bisa saja tidak hanya sekadar bagaimana menjual produk yang dijual dengan mengemas pesan yang hanya menampilkan keunggulan semata-semata suatu produk, namun akan lebih elegan seandainya dalam beriklan memiliki jalan cerita yang sarat makna sehingga memiliki nilai bagi audiens yang menonton, seperti yang telah disinggung oleh peneliti bahwa Iklan Susu Frisian Flag Gold Edisi Ramadhan sarat akan nilai dakwah.

Berpuasa adalah kewajiban bagi semua umat Islam yang telah memenuhi syarat atau rukunnya. Setiap setahun sekali selama bulan ramadhan satu bulan penuh kaum muslimin harus melakukan ibadah puasa bahkan sangat diutamakan semakin meningkatkan kapasitas ibadah karena pada bulan ini adalah bulan penuh berkah dan ampunan dari Allah Swt. Bukan hal yang asing apabila penyambutan suasana Ramadhan sangat beragam, lebih meriah dari suasana bulan lainnya misalkan di tiap daerah maupun kelompok sosial di Indonesia memiliki kekhasan tertentu dalam menyambut puasa mulai dari aktivitas sahur diantaranya adalah keliling kampung (komplek) untuk membangunkan warga untuk segera sahur bahkan hingga menjelang berbuka puasa dengan semaraknya aktivitas jual beli yakni penjual menjajakan beragam jenis kuliner untuk berbuka, hingga diwaktu setelah berbuka puasa bahkan sampai aktivitas safari tarawih yakni melaksanakan shalat tarawih keliling antara satu masjid ke masjid lainnya.

Gambaran dari realita kehidupan di masyarakat khususnya dalam suasana ramadhan dapat juga dituangkan oleh pengiklan dalam iklan produk yang ingin dijual dengan mengangkat realita tersebut dalam sebuah cerita iklan. Iklan Susu Frisian Flag Gold ini juga mengangkat sisi realita di masyarakat dalam menyambut bulan ramadhan.

\footnotetext{
${ }^{4}$ Ismail Tunany, Manajemen Pers Dakwah (Jakarta: Graha Guru, 2007), p. 18.
} 
Iklan ini menampilkan alur cerita dalam sebuah keluarga kecil yang terdiri dari empat inti anggota keluarga yakni ayah, ibu dan dua orang anak, laki-laki (kakak) dan adik (perempuan) dalam suasana berpuasa di mana sang kreator iklan mengangkat suasana menjalankan ibadah puasa bermula dari sahur yakni makan bersama-sama hingga berbuka puasa.

Suasana sahur dengan berkumpul di meja makan bersama anggota keluarga terasa begitu ceria, menyenangkan, menggambarkan kekompakkan yang tervisualisasi dalam iklan ini apalagi pada saat sahur disuguhkan susu kental manis (Susu Frisian Flag Gold) yang mengandung nutrisi untuk diminum semua anggota keluarga sehingga efek dari nutrisi itu dapat menyehatkan tubuh yang berdampak pada aktivitas sehari-hari yang tidak terganggu walaupun sedang berpuasa, hal ini tergambar dari ayah yang tetap bekerja penuh semangat, ibu yang membereskan urusan rumah tangga tetap menampilkan senyum manisnya dan anak-anak yang tetap bersemangat bersekolah dan bersepeda. Apalagi sampai menyambut waktu berbuka puasa susu kental manis ini tetap memiliki kesan tersendiri dalam keluarga bagaimana susu dengan merk ini dapat juga menambah kelengkapan untuk menu berbuka puasa yakni melengkapi minuman dingin berupa minuman es campur sebagai obat dari rasa menahan dahaga setelah sepanjang hari berpuasa.

Hal tersebut sengaja dimunculkan untuk mengangkat sisi keunggulan dari Susu Frisian Flag Gold. Pengiklan mencoba untuk menegaskan sisi-sisi manfaat setelah mengkonsumsi iklan tersebut. Selain itu menariknya dalam iklan ini terdapat tandatanda yang mengandung nilai dakwah yang dapat diambil pembelajarannya bagi yang menonton iklan tersebut. Hal ini lah yang menarik perhatian bagi peneliti adalah fokus dari riset ini yakni peneliti ingin melihat nilai-nilai dakwah apa saja yang terkandung dalam iklan tersebut dengan judul penelitian Representasi Nilai Dakwah dalam Iklan Susu Frisian Flag Gold Edisi Ramadhan 2017. Untuk menilai makna-makna nilai dakwah yang ditampilkan melalui iklan ini, seperti nilai yang terwakilkan baik dari nilai lisan, tulisan ataupun nonverbal, maka peneliti akan menganalisis iklan ini melalui pisau analisis semiotika dengan menggunakan teori Roland Barthes yakni peneliti akan mengkaji mengenai berbagai kemungkinan penggunaan tanda berikut makna yang berkaitan dengan nilai dakwah. 
Berdasarkan latar masalah di atas, maka permasalahan-permasalahan yang dirumuskan adalah sebagai berikut: Bagaimana pengiklan menggunakan tanda-tanda dalam iklan Susu Frisian Flag Gold Edisi Ramadhan 2017 terkait dengan nilai-nilai dakwah yang terkandung dalam iklan tersebut? Makna apa yang dapat diinterpretasikan melalui penggunaan tanda-tanda yang berkaitan dengan nilai-nilai dakwah dalam iklan Susu Frisian Flag Gold edisi Ramadhan 2017?

Melalui perumusan masalah diatas maka tujuan dari penelitian ini adalah untuk: 1) Mengetahui tanda-tanda yang berkaitan dengan nilai-nilai dakwah melalui iklan Susu Frisian Flag Gold Edisi Ramadhan 2017; 2) Mengetahui makna dibalik penggunaan tandatanda yang berkaitan dengan nilai-nilai dakwah dalam iklan Susu Frisian Flag Gold edisi Ramadhan 2017.

Selanjutnya, penelitian ini mempunyai beberapa manfaat: manfaat akademis yaitu: 1) penelitian ini diharapkan dapat bermanfaat bagi perkembangan ilmu komunikasi khususnya dari sudut kajian periklanan ilmu semiotika; 2) Penelitian ini dapat menjadi masukan bagi penelitian selanjutnya dalam pembahasan mengenai representasi nilai-nilai dakwah yang terdapat dalam sebuah iklan. Sedangkan manfaat praktisnya, agar hasil dari penelitian ini diharapkan dapat menjadi bahan kajian bagi para pengiklan sebagai bahan masukan dalam merancang iklan yang akan menggunakan atau merepresentasikan nilai-nilai dakwah.

\section{B. Komunikasi Sebagai Proses Simbolik dan Pertukaran Makna}

Lambang atau simbol adalah sesuatu yang digunakan untuk menunjuk suatu lainnya, berdasarkan kesepakatan sekelompok orang. Lambang meliputi kata-kata (pesan verbal), perilaku non verbal dan objek yang maknanya disepakati bersama. Beberapa sifat lambang yang dapat diketahui diantaranya:

1. Lambang bersifat sebarang, manasuka atau sewenang-wenang

Apa saja bisa dijadikan lambang, bergantung pada kesepakatan bersama. Lambang dapat hadir dimana-mana dan tidak henti-hentinya menerpa kita. Diantara bentuk lambang-lambang adalah berupa kata-kata (lisan atau tulisan), isyarat anggota tubuh, makanan dan cara makan, tempat tinggal, jabatan (pekerjaan), olahraga, hobi , peristiwa, hewan, tumbuhan, gedung, alat (artefak), angka, bunyi, waktu dan sebagainya.Namun alam tidak memberikan penjelasan kepada kita mengapa manusia 
menggunakan lambang-lambang tertentu untuk merujuk pada hal-hal tertentu baik yang konkret aatupun abstrak.

2. Lambang pada dasarnya tidak mempunyai makna; kitalah yang memberi makna pada lambang

Makna sebenarnya ada dalam kepala kita, bukan terletak pada lambang itu sendiri. Kalaupun ada orang yang mengatakan bahwa kata-kata mempunyai makna, yang ia maksudkan sebenarnya bahwa kata-kata itu mendorong orang untuk memberi makna (yang telah disetujui bersama) terhadap kata-kata itu. Persoalan akan timbul bila para peserta komunikasi tidak memberi makna yang sama pada suatu kata.

3. Lambang itu bervariasi

Lambang itu bervariasi dari suatu budaya ke budaya lain, dari suatu tempat ke tempat lain, dan dari suatu konteks waktu ke konteks waktu lain.Begitu juga makna yang diberikan kepada lambang tersebut.Pendek kata, kita hanya memerlukan kesepakatan mengenai suatu lambang. Makna yang diberikan kepada suatu lambang boleh jadi berubah dalam perjalanan waktu, meskipun perubahan makna itu berjalan lambat. ${ }^{5}$

\section{Iklan}

Iklan merupakan salah satu cara yang dapat digunakan perusahaan untuk melakukan promosi dalam menarik pelanggan. Pemasangan iklan pun dapat kita temui dari berbagai macam media beriklan baik pemasangan melalui media cetak, media elektronik, billboard maupun media lainnya. Ada empat hal yang menjadi tujuan penggunaan iklan yakni:

1. Untuk pemberitahuan tentang segala sesuatu yang berkaitan dengan produk yang dimiliki oleh suatu perusahaan, seperti peluncuran produk baru, keuntungan dan kelebihan suatu produk atau informasi lainnya;

2. Untuk mengingatkan kembali kepada pelanggan tentang keberadaan atau keunggulan produk yang ditawarkan;

3. Untuk perhatian dan minat para pelanggan baru dengan harapan akan memperoleh daya tarik dari para calon pelanggan.

${ }^{5}$ Deddy Mulyana, Ilmu Komunikasi: Suatu Pengantar (Bandung: PT Remaja Rosdakarya, 2009), pp. 
4. Memengaruhi pelanggan saingan agar berpindah ke produk dari perusahaan yang mengiklankan 6 .

Beberapa pertimbangan dalam penggunaan media untuk pemasangan iklan disuatu media:

1. Jangkauan media yang akan digunakan;

2. Sasaran atau konsumen yang akan dituju;

3. Besarnya biaya yang akan dikeluarkan. ${ }^{7}$

\section{Semiotika dalam Teori Roland Barthes}

Secara etimologis, semiotika berasal dari bahasa yunani semeion yang berarti tanda. Tanda pada awalnya dimaknai sebagai suatu hal yang menunjuk adanya hal lain. Secara terminologis semiotika dapat diidentifikasikan sebagai ilmu yang mempelajari sederetan luas objek-objek, peristiwa-peristiwa, seluruh kebudayaan sebagai tanda. ${ }^{8}$

Teori yang digunakan dalam riset ini adalah teori Roland Barthes. Barthes adalah ahli semiotika yang melontarkan konsep tentang konotasi dan denotasi sebagai kunci dari analisisnya. Barthes mendefinisikan sebuah tanda (sign) sebagai sebuah sistem yang terdiri dari (E) sebuah ekpresi atau signifier dalam hubungannya (R) dengan content (atau signified) (C): ERC. Lewat model ini Barthes menjelaskan bahwa signifikansi tahap pertama merupakan hubungan antara signifier (ekspresi) dan signified (content) di dalam sebuah tanda terhadap realitas external. Itu yang disebut Barthes sebagai denotasi yaitu makna yang paling nyata dari tanda (sign). Konotasi adalah istilah yang digunakan Barthes untuk menunjukkan signifikansi tahap kedua. Hal ini menggambarkan interaksi yang terjadi ketika tanda bertemu dengan perasaan atau emosi dari pembaca serta nilainilai dari kebudayaannya. Konotasi mempunyai makna yang subjektif atau paling tidak intersubjektif. 9

Gambar 1. Signifikansi Semiotika Roland Barthes

\footnotetext{
${ }^{6}$ Kasmir, Kewirausahaan (Raja Grafindo Persada: Jakarta, 2010), p. 184.

${ }^{7}$ Ibid.

8 Wibowo, Semiotika Komunikasi, p. 5.

9 Wibowo, Semiotika Komunikasi, pp. 16-7.
} 


\begin{tabular}{|l|l|l|l|}
\hline $\begin{array}{l}\text { Lang/ } \\
\text { Code }\end{array}$ & 1. Signifier & 2. Signified & \\
\hline 3yth & 2. Sign & \\
\hline 3.SIGN & \\
\hline
\end{tabular}

\section{E. Metodologi Penelitian}

Adapun jenis penelitian dalam penelitian ini menggunakan pendekatan kualitatif yakni bertujuan untuk menjelaskan fenomena dengan sedalam-dalamnya melalui pengumpulan data sedalam-dalamnya. Riset ini tidak mengutamakan besarnya populasi atau sampling bahkan populasi atau samplingnya sangat terbatas. Disini yang lebih ditekankan adalah persoalan kedalaman (kualitas) data bukan banyaknya (kuantitas) data. ${ }^{10}$

Metode pengumpulan data adalah teknik atau cara-cara yang dapat digunakan periset untuk mengumpulkan data. ${ }^{11}$ Dalam penelitian ini peneliti akan mengumpulkan data melalui teknik observasi (pengamatan) dengan mengamati iklan Susu Frisian Flag Gold yang merupakan studi dokumentasi untuk dijadikan sebagai data primer yang peneliti dapatkan sumbernya dari media audio visual. Peneliti akan mengamati tandatanda meliputi verbal (lisan dan tulisan) serta nonverbal dari sejumlah visualisasi terpilih dari iklan Susu Frisian Flag Gold Edisi Ramadhan 2017.

Peneliti dalam hal ini berperan sebagai bagian integral dari data artinya peneliti ikut aktif dalam menentukan jenis data yang diinginkan. Dengan demikian, periset menjadi instrumen riset yang harus terjun langsung di lapangan, ${ }^{12}$ sedangkan sebagai data sekunder peneliti melakukan telaah dari berbagai macam sumber diantaranya buku dan sumber internet sebagai data pendukung penelitian ini.

Peneliti akan meneliti iklan Susu Frisian Flag Gold Edisi Ramadhan 2017 namun dalam penelitian ini peneliti tidak akan meneliti semua adegan yang terdapat dalam iklan

${ }^{10}$ Racmat Kriyantono, Riset Komunikasi: Teknik Praktis Disertai Contoh Praktis Riset Media, Public Relations, Advertising, Komunikasi Organisasi, Komunikasi Pemasaran (Jakarta: Kencana Prenada Media Group, 2007), p. 58.

11 Ibid., p. 91.

12 Ibid., pp. 58-9. 
tersebut. Penelitian hanya akan memfokuskan pada tanda-tanda yang terdapat dalam iklan ini terkait mewakili nilai-nilai dakwah, baik tanda-tanda yang terdapat pada aspek visual (gambar) yakni komunikasi verbal ataupun nonverbal ataupun aspek suara (audio) dari iklan ini yang diperankan oleh keempat bintang iklan ini. Oleh karena unit analisis ini dipersempit oleh peneliti maka apabila ditemukan oleh peneliti terdapat adegan-adegan yang tidak terkait dengan nilai dakwah tidak akan peneliti kaji.

Analisis adalah proses menyusun data agar dapat ditafsirkan. Menyusun berarti menggolongkannya dalam pola, tema atau kategori. Tanpa kategorisasi atau klasifikasi data, akan terjadi chaos. Tafsiran atau interpretasi artinya memberikan makna kepada analisis, menjelaskan pola atau kategori, mencari hubungan antara berbagai konsep. ${ }^{13}$ Semua informasi data yang terkumpul oleh peneliti akan dianalisis secara kualitatif yakni menggunkan pisau semiotika menurut teori Roland Barthes dan peneliti hanya membatasi pada tataran pertama teori Roland Barthes makna denotasi dan konotasi. Peneliti akan memilih adegan-adegan dari urutan cerita (storyboard) yang menggunakan sejumlah tanda yang memiliki kaitan dengan nilai-nilai dakwah dari iklan yang sudah ditentukan oleh peneliti.

Selanjutnya peneliti akan melakukan seleksi dari bingkai (frame) yang memuat tanda-tanda yang memiliki keterkaitan dengan nilai-nilai dakwah seperti yang dikutip oleh Alex Sobur dari Cobley dan Janzs yang memilah pesan iklan menjadi tiga kategori menurut teori Roland Barthes berupa:

1. Pesan linguistik, yang merupakan semua kata dan kalimat dalam iklan;

2. Pesan ikonik yang terkodekan, berupa konotasi yang muncul dalam foto iklan, yang hanya dapat berfungsi jika dikaitkan dengan sistem tanda yang lebih luas dalam masyarakat;

3. Pesan ikonik tak terkodekan, yaitu denotasi dalam foto iklan. ${ }^{14}$

\section{F. Hasil Penelitian}

m Pada pembahasan sebelumnya telah dipaparkan bahwa tujuan dari penelitian ini adalah untuk menggali representasi nilai -nilai dakwah yang terkandung dalam pesan iklan Susu Frisian Flag Gold Edisi Ramadhan 2017 dengan menggunakan metode analisis

\footnotetext{
13 Ibid.

${ }^{14}$ Alex Sobur, Semiotika komunikasi (Bandung: PT Remaja Rosdakarya, 2004), p. 69.
} 
sistem pertandaan bertingkat dari Roland Barthes yang akan dibatasi dari sisi denotasi dan konotasi. Tahap ini akan dimulai dengan memaparkan makna denotasi tanda dan pada tahap lanjutan akan dibahas tentang makna konotasi tanda dibalik penggunaan tanda-tanda nilai dakwah.

Untuk memudahkan membaca peta hasil dan analisis dari penelitian ini maka peneliti akan menampilkan storyboard dan story line sesuai dengan tujuan iklan ini. Peneliti akan memilih adegan-adegan yang menurut peneliti penting dengan menyusun secara frame by fame sehingga dapat dengan mudah memahami rangkaian cerita iklan ini yang dalam hal ini mudah menginterpretasi bagaimana nilai dakwah yang tergambar dibulan ramadhan dimulai dari waktu sahur hingga menjelang berbuka puasa.

Tahap selanjutnya adalah peneliti akan membagi pesan iklan sesuai dengan teori yang digunakan Roland Barthes meliputi:

1. Pesan linguistik, yang merupakan semua kata dan kalimat dalam iklan;

2. Pesan ikonik yang terkodekan, berupa konotasi yang muncul dalam foto iklan, yang hanya dapat berfungsi jika dikaitkan dengan sistem tanda yang lebih luas dalam masyarakat;

3. Pesan ikonik tak terkodekan, yaitu denotasi dalam foto iklan.

\section{Storyboard}

Berikut ini adalah storyboard (jalan cerita) Iklan Susu Frisian Flag Gold Edisi Ramadhan 2017:

\begin{tabular}{|l|l|}
$\begin{array}{l}\text { Ayah, ibu, kakak dan adik sedang } \\
\text { duduk dimeja makan } \\
\text { SFX: Musik instrumen } \\
\text { Announcer: Dibulan ramadhan ini }\end{array}$ & $\begin{array}{l}\text { 2.Adik tersenyum senang melihat segelas susu yang disodorkan ibu untuk dirinya } \\
\text { Adik (FVO): "Waaah.." } \\
\text { Announcer : Dibuan ramadhan ini }\end{array}$ \\
\hline
\end{tabular}

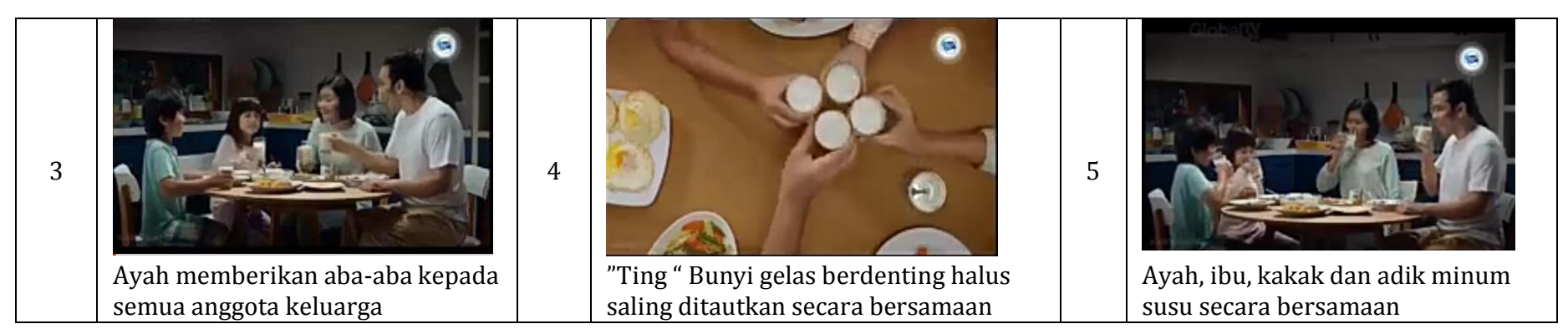


Mawaizh

Jurnal Dakwah dan Pengembangan Sosial Kemanusiaan

Vol. 9, no. 1 (2018), pp. 18-39

\begin{tabular}{|c|c|c|c|c|c|}
\hline & $\begin{array}{l}\text { SFX: Musik instrumen } \\
\text { Announcer: Awali dengan segelas } \\
\text { nutrisi }\end{array}$ & & $\begin{array}{l}\text { SFX : Musik instrumen } \\
\text { Announcer: Awali dengan segelas } \\
\text { nutrisi }\end{array}$ & & $\begin{array}{l}\text { SFX: Musik instrumen } \\
\text { Announcer: Awali dengan segelas } \\
\text { nutrisi }\end{array}$ \\
\hline 6 & $\begin{array}{l}\text { Kakak yang mencium tangan Ibu } \\
\text { untuk pamit ke sekolah, } \\
\text { sementara adik melambaikan } \\
\text { tangan dari balik mobil } \\
\text { SFX: Musik instrumen } \\
\text { Announcer: Awali dengan segelas } \\
\text { nutrisi }\end{array}$ & 7 & $\begin{array}{l}\text { Ayah nampak semangat menaiki anak } \\
\text { tangga kantor sembari menyapa } \\
\text { teman kantor } \\
\text { MVO Ayah: "Hei Ga." } \\
\text { "Ayo meeting" } \\
\text { SFX : Musik instrumen } \\
\text { Announcer : Penuh semangat jalani hari }\end{array}$ & 8 & $\begin{array}{l}\text { Adik nampak semangat menaiki } \\
\text { tangg sambil berbicara dengan } \\
\text { teman } \\
\text { FVO Adik : “Aku bantu ya” } \\
\text { SFX : Musik instrumen } \\
\text { Announcer : Penuh semangat jalani } \\
\text { hari }\end{array}$ \\
\hline 9 & $\begin{array}{l}\text { Ibu menampilkan keceriaan } \\
\text { terlihat dari wajahnya. Tampak } \\
\text { ibu baru menerima sebuah } \\
\text { bingkisan } \\
\text { SFX: Musik instrumen } \\
\text { Announcer : Penuh semangat jalani } \\
\text { hari }\end{array}$ & 10 & $\begin{array}{l}\text { Kakak bersantai bermain sepeda } \\
\text { dengan tersenyum ceria } \\
\text { SFX: Musik instrumen } \\
\text { Announcer : Penuh semangat jalani hari }\end{array}$ & 11 & $\begin{array}{l}\text { Ibu, kakak dan adik menyambut } \\
\text { kedatangan ayah } \\
\text { FVO Adik :" Ayah pulang" SFX: } \\
\text { Musik instrumen } \\
\text { Announcer : Penuh semangat jalani } \\
\text { hari }\end{array}$ \\
\hline 12 & $\begin{array}{l}\text { Close up Susu Frisian Flag Gold } \\
\text { SFX: Musik instrumen } \\
\text { Announcer: Bersama Frisian Flag } \\
\text { Gold untuk kemenangan yang } \\
\text { manis }\end{array}$ & 13 & $\begin{array}{l}\text { Adik membayangkan enaknya } \\
\text { menikmati es campur } \\
\text { FVO (Adik) : "eemmm.." } \\
\text { SFX: Musik instrumen } \\
\text { Announcer: Bersama Frisian Flag Gold } \\
\text { untuk kemenangan yang manis }\end{array}$ & 14 & $\begin{array}{l}\text { Close up susu kental manis } \\
\text { dituangkan sebagai topping es } \\
\text { campur } \\
\text { SFX: Musik instrumen } \\
\text { Announcer: Bersama Frisian Flag } \\
\text { Gold untuk kemenangan yang } \\
\text { manis }\end{array}$ \\
\hline 15 & $\begin{array}{l}\text { Adik tampak buru-buru ingin } \\
\text { segera mengecap susu kental } \\
\text { manis } \\
\text { SFX: Musik instrumen }\end{array}$ & 16 & $\begin{array}{l}\text { Ayah, Ibu dan Kakak mencegah adik } \\
\text { untuk tidak mencicipi susu kental } \\
\text { manis }\end{array}$ & 17 & $\begin{array}{l}\text { Bedug berbunyi dan adik pun } \\
\text { segera mengecap susu kental manis } \\
\text { bah semua keluarga tertawa }\end{array}$ \\
\hline
\end{tabular}


Mawa'izh

Jurnal Dakwah dan Pengembangan Sosial Kemanusiaan

Vol. 9, no. 1 (2018), pp. 18-39

\begin{tabular}{|l|l|l|l|}
\hline $\begin{array}{l}\text { Announcer: Awali dengan nutrisi } \\
\text { akhiri dengan manis Bersama } \\
\text { Frisian Flag Gold }\end{array}$ & $\begin{array}{l}\text { FVO (Ibu):"eeh..” (melarang adik) } \\
\text { MVO (Kakak) : "Belum..belum" } \\
\text { Announcer: Awali dengan nutrisi } \\
\text { akhiri dengan manis Bersama Frisian } \\
\text { Flag Gold }\end{array}$ & $\begin{array}{l}\text { SFX: Bunyi bedug } \\
\text { Announcer: Awali dengan nutrisi } \\
\text { akhiri dengan manis Bersama } \\
\text { Frisian Flag Gold }\end{array}$ \\
\hline
\end{tabular}

Berikut keterangan istilah periklanan dari storyboard diatas:

Announcer /Anncr

Female Voice Over/FVO

Male Voice Over/MVO

Sound Effect dalam skrip/SFX

\section{Storyboard}

Storyline
: Narator di dalam iklan radio (biasanya menceritakan product info)

: Dubber/pengisi suara dalam iklan khusus wanita

: Dubber/pengisi suara dalam iklan khusus wanita

: Suara selain musik atau kata-kata yang digunakan untuk membantu menciptakan image, membangkitkan emosi, memadatkan waktu, menjelaskan situasi atau menguatkan pesan

: Jalan cerita rencana iklan TV dalam bentuk gambar bersambung/komik

: jalan cerita rencana iklan TV dalam bentuk tulisan ${ }^{15}$

\section{Storyline}

Iklan Susu Frisian Flag Gold Edisi Ramadhan 2017 ini berdurasi 30 detik. Iklan ini menceritakan kehidupan sebuah keluarga pada suasana bulan ramadhan. Tampilan iklan ini menayangkan sosok ayah, ibu, kakak dan adik yang berkumpul bersama di dapur hal ini terlihat dari kursi, serta sejumlah makanan diatas meja makan. Dalam iklan ini pengiklan menayangkan aktivitas keseharian dalam berpuasa yakni aktivitas pada saat sahur (sebelum waktu subuh), aktivitas diluar rumah (pagi sampai sore hari) hingga aktivitas menjelang magrib (sebelum berbuka puasa).

Pada adegan pertama terlihat suasana berkumpulnya keluarga dalam waktu sahur terlihat dari seorang ibu yang sedang menyiapkan menu sahur dan minuman pertama sebagai menu sahur yang disuguhkan kepada keluarganya adalah susu kental manis Frisian Flag Gold yang disambut dengan senyuman oleh anggota keluarga ketika akan minum produk tersebut. Adegan selanjutnya dalam iklan ini menggambarkan bagaimana aktivitas anggota keluarga tetap seperti biasa dijalani yakni ayah bekerja, ibu

\footnotetext{
15 devychandra15.blogspot.com
} 
mengurusi keperluan rumah tangga dan anak-anak bersekolah dengan tetap ceria, penuh semangat melewati waktu berpuasa.

Selanjutnya adegan sore hingga menjelang berbuka puasa tetap disambut dengan suasana ceria yakni kakak terlihat asyik bersantai bersepeda dan bersama Ibu dan adik semangat menyambut kepulangan ayah dari tempat kerja. Adegan selanjutnya adalah menjelang berbuka puasa, ibu sedang sibuk menyiapkan menu berbuka puasa dengan menonjolkan produk susu kental manis Frisian Flag Gold kembali yang dapat menjadi pelengkap es campur yang akan diminum pada saat berbuka puasa. Hal ini membuat sang adik tidak sabaran untuk segera mencicipi susu kental manis yang terlihat dari mimik wajah, suara dan isyarat tangan namun ayah, ibu dan kakak yang berada disampingnya segera mencegah agar jangan mencicipi dulu karena akan membatalkan puasa. Barulah setelah terdengar suara azan adik langsung mengecap susu kental manis tersebut untuk menjawab rasa penasarannya.

\section{Interpretasi iklan Susu Frisian Flag Gold Edisi Ramadhan 2017}

Peneliti akan menganalisis iklan Susu Frisian Flag Gold ini yang berkaitan dengan potongan -potongan gambar iklan (baca dari urutan kiri ke kanan) dari hasil pengamatan diatas. Untuk memudahkan analisis peneliti akan membagi dalam tiga adegan yakni pada saat sahur, aktivitas siang hari, aktivitas sore hari menjelang berbuka puasa yang dilakukan oleh anggota keluarga. Sesuai dengan tujuan penelitian, peneliti akan membatasi hanya dengan memfokuskan adegan-adegan yang memiliki kaitan dengan nilai dakwah.

\section{a. Aktivitas Sahur (Adegan 1)}

Aktivitas sahur ini terlihat dari Ibu yang sedang menyiapkan menu sahur yang sedang berdiri untuk menyuguhkan makanan (Signifier). Dari shot 1 ini terlihat bagaimana sosok istri yang harus memberikan pelayanan kepada keluarga.Dalam ajaran Islam seorang istri berkewajiban untuk dapat melayani keluarga diantaranya menyiapkan makanan kepada anggota keluarga . Istri harus membantu suami dalam melayani kepentingan keluarga (Signified).

Dari Shot 2 terlihat anak menampilkan ekpresi senang ketika melihat susu yang disuguhkan Ibu dan mengatakan "Waah..” (Signifier). Senyuman (non verbal) dan mengatakan" waah " (verbal) adalah bentuk kekaguman terhadap suatu objek. Fungsi komunikasi nonverbal tergambar sebagai penegasan bahwa adik merasa bahagia 
disuguhkan susu (signified). Shot 3 sampai 5 adalah menceritakan ayah memberikan abaaba (shot 3), lalu semua gelas ditautakan menimbulkan bunyi ting (shot 4) dan semua anggota keluarga minum susu secara bersamaan (shot 5) (Signifier). Ayah yang memberikan aba-aba (kode) dengan intonasi suara yang bahagia dapat mempengaruhi suasana ketentraman dalam keluarga dan adanya bunyi gelas yang berdenting menguatkan adanya kekompakan.

Kekompakan dalam keluarga berupa interkasi sosial yang baik dalam keluarga akan menghasilkan rumah tangga yang menentramkan (Signified). Berikut storyboarad dari adegan pertama iklan ini :

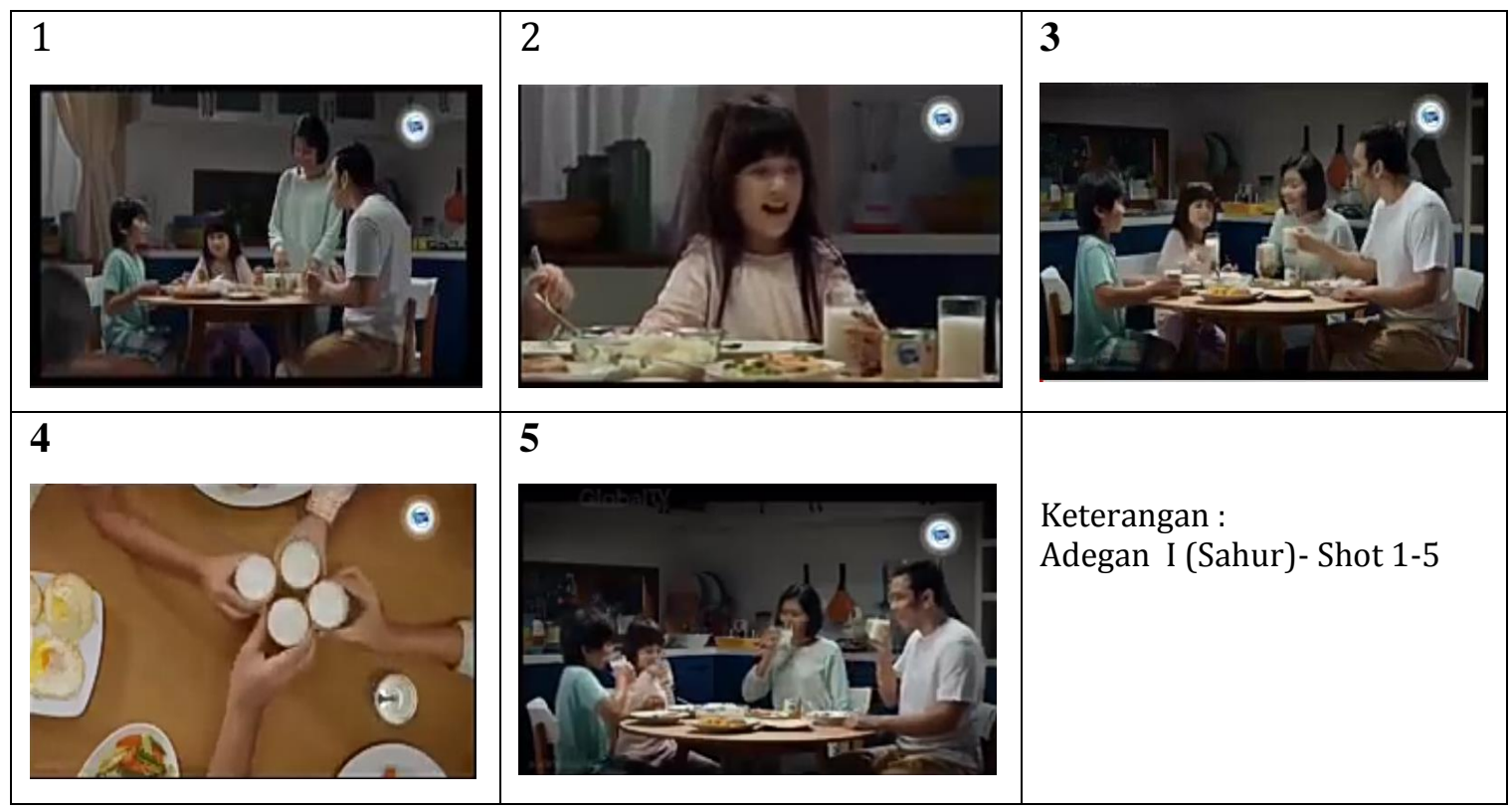

\section{b. Aktivitas Siang Hari (Adegan II)}

Aktivitas dari pagi hingga siang hari juga diangkat oleh pengiklan di iklan ini. Terlihat sosok anak yang akan pamit pergi ke sekolah dengan mencium tangan sang Ibu (Shot 1).Dalam Islam adalah suatu kewajiban bagi anak untuk memberikan hormat kepada orang tua salah satunya dengan mencium tangan Ibu untuk menunjukkan rasa hormat, menghargai sehingga dapat menyenangkan orang tua (Signified). Shot 2 menggambarkan sosok ayah yang tetap enerjik dikantor dengan menaiki anak tangga sembari menyapa ramah teman sekantor " Hei Ga." "Ayo meeting" (Signifier). Dari adegan ini tergambar bahwa ayah yang berperan sebagai kepala keluarga terlihat bertanggung jawab keluarga bekerja mencari nafkah yang merupakan kewajiban sebagai kepala keluarga dan sesama muslim memang harusnya bersikap ramah kepada siapapun sesuai dengan ajaran Islam (Signified). 
Pada shot 3 terlihat sang adik juga tetap bersemangat bersekolah dengan menaiki tangga sembari menawarkan bantuan kepada teman sebelahnya "Aku bantu ya" (Signifier), shot 3 ini menunjukkan bahwa dengan menahan nafsu makan minum bagi yang berpuasa bukan berarti akan menyurutkan semangat, lemas tidak bergairah dalam beraktivitas justru semakin menguatkan semangat untuk menolong orang (teman). Dalam Islam menolong sesama manusia adalah kewajiban dengan menolong orang lain maka akan semakin mempererat persaudaraan, menjaga kerukunan (Signified).

Sedangkan dari shot 4 sampai dengan shot 6 terlihat bagaimana Ibu tetap ceria dalam aktivitas keseharian dirumah, kakak yang tetap tesenyum ceria disore hari sembari bersepeda dan kakak juga bersama Ibu dan adik terlihat gembira menyambut kedatangan ayah yang baru pulang dari tempat kerja (signifier). Sebagai seorang muslim adalah keharusan menampilkan senyuman manis kepada siapapun karena senyuman manis adalah gambaran keramahan kita kepada orang lain, senyum bernilai ibadah (Signified). Berikut storyboarad dari adegan kedua iklan ini :

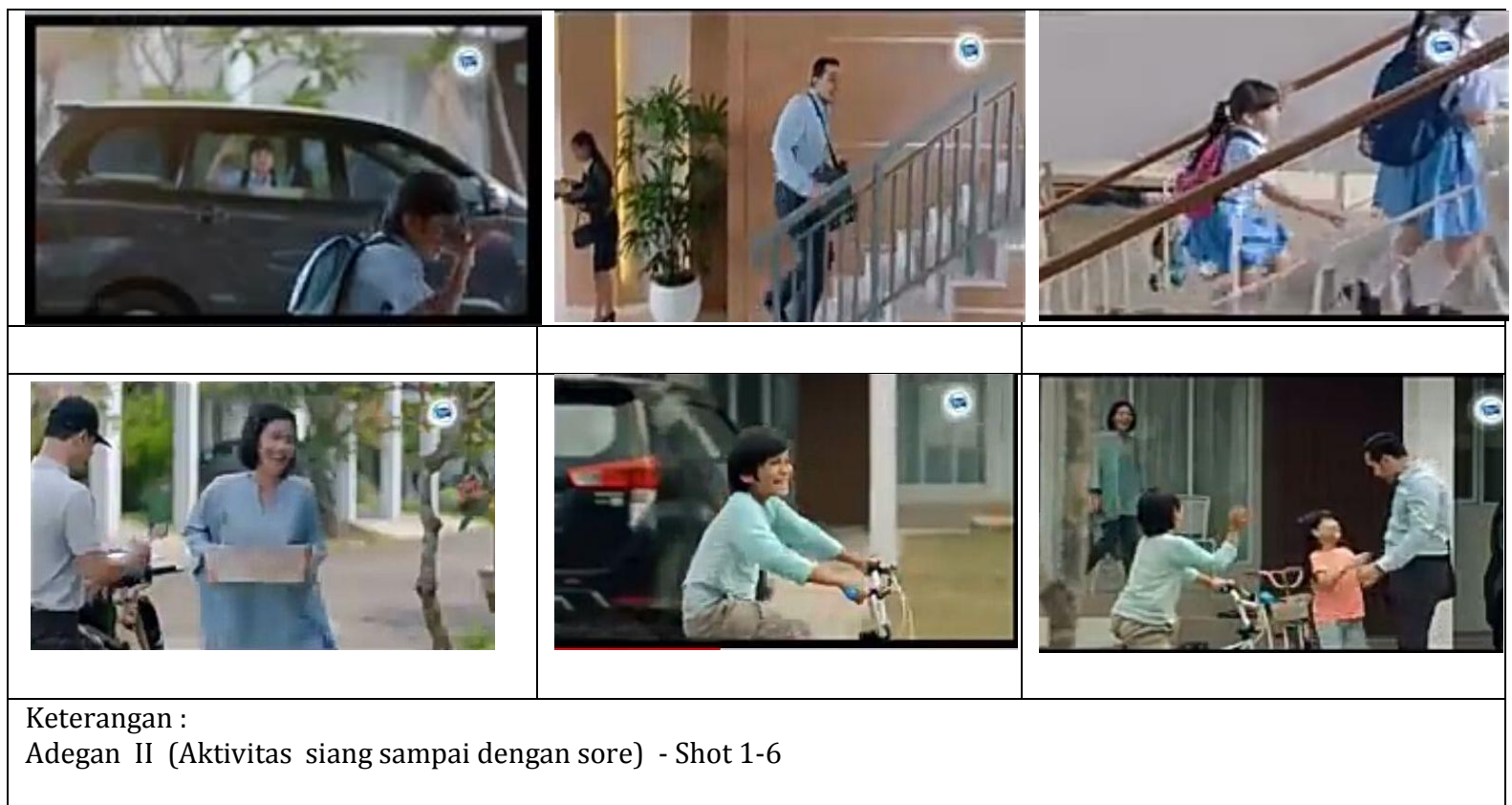

\section{c. Aktivitas Sore Menyiapkan Moment Berbuka Puasa (Adegan III)}

Pada adegan ke 3 ini terlihat produk Susu Frisian Flag Gold di tampilkan secara dekat/close up, pengiklan menunjukkan kemasan berikut juga tampilan isi dari susu kental manis (Signifier). Pada shot 2 terlihat adik begitu senang melihat es campur yang dipadukan dengan susu kental manis sehingga tidak sabar untuk segera mencicipi enaknya es campur yang dipadankan dengan susu (signifier). Bertopang dagu menatap 
es campur sambil membayangkan dengan mengucapkan intonasi eemmm. Menunjukkan ada unsur kelezatan dari es campur (signified).

Pada shot 3 pengiklan memfokuskan pada gambar es campur yang menggambarkan kelezatan apalagi ditambah topping susu kental manis (signifier).Pada shot 4 dan 5 digambarkan adik segera ingin segera mencicipi susu kental manis yang terdapat pada es campur namun hal itu segera dicegah oleh anggota keluarga lainnya dari gerakan tangan yang menandakan untuk mencegah diperkuat dengan kalimat"Belum..belum” (Signifier). Shot 4 dan 5 ini sengaja didesain pengiklan bahwa pada kenyataannya bagi yang sedang berpuasa memiliki banyak godaan, dari iklan ini terlihat adik yang sedang tersenyum menopang dagu sambil membayangkan lezatnya nya es campur. Hal ini biasa terjadi pada saat orang berpuasa banyak terdapat cobaan sehingga apabila tidak dicegah karena khawatir akan terlanjur mencicipi menu buka puasa yang akan berpotensi membatalkan puasa (signified) dan pada shot 6 pada saat bedug sudah berbunyi maka adik segera mencicipi susu kental manis dan keluarga pun tersenyum ceria yang ditutup dengan tulisan awali dengan nutrisi akhiri dengan manis (signifier). Bunyi bedug menandakan bahwa waktu magrib sudah tiba dan saatnya bagi umat Islam yang berpuasa untuk segera berbuka.

Berikut storyboarad dari adegan ketiga iklan ini :
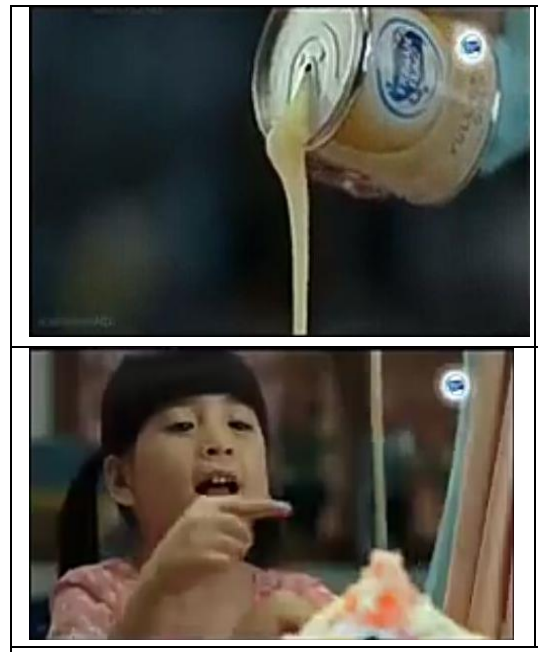

Keterangan :

Adegan III (Aktivitas siang sampai dengan sore)

Shot 1-6
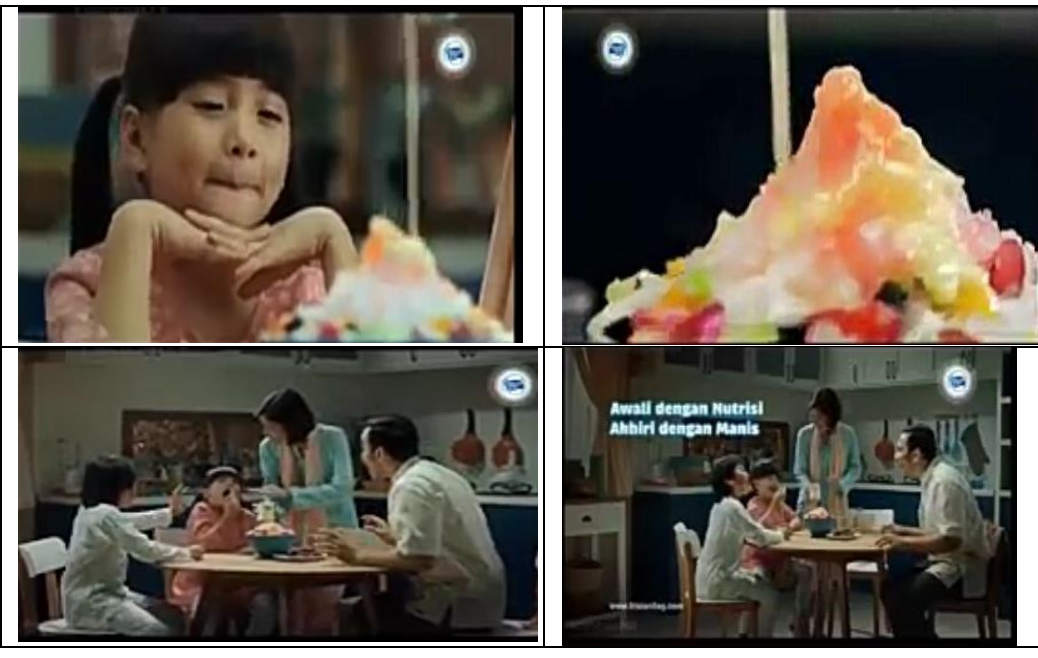

Dari Iklan Susu Frisian Flag Gold ini peneliti menilai ada beberapa nilai dakwah yang terkait. Secara keseluruhan peneliti melihat ada usaha pengiklan untuk mendesain iklan yang menunjukkan manfaat dari beberapa hal setelah mengkonsumsi susu kental 
manis yakni berfungsi sebagai nutrisi dan dapat menjadi pelengkap makanan. Tidak hanya itu nilai dakwah juga diangkat oleh pengiklan. Menurut hemat peneliti hal ini tidak lepas dari moment atau suasana ramadhan sehingga pesan-pesan yang disampaikan pun juga bernilai unsur religi. Berikut beberapa nilai dakwah yang dapat diangkat dari iklan ini yakni adanya nilai kebersamaan, rasa hormat anak kepada orang tua, ayah yang menjalankan perannya sebagai sosok kepala keluarga untuk mencari nafkah, ibu yang menjalani perannya dalam melayani suami dan anak-anak, ayah dan ibu yang ramah tersenyum, berbuka puasa diwaktu yang tepat.

Adegan pertama yang diangkat dalam iklan ini menggambarkan suasana menyambut sahur.Sahur adalah aktivitas makan yang dilakukan oleh kaum muslimin yang akan menjalankan ibadah puasa, aktivitas makan ini dapat dilakukan pada dini hari hingga sebelum memasuki waktu subuh. Agar aktivitas puasa tidak terganggu sehingga nilai ibadah tetap maksimal maka kondisi tubuh harus tetap dijaga yakni dengan cara mengkonsumsi makanan /minuman yang mengandung nutrisi agar kondisi tubuh tetap fit.Pengiklan mencoba menyodorkan susu kental manis dalam pembukaan sahur ini sehingga menegaskan pilihan yang pertama diutamakan dari sekian jenis menu yang tersedia dimeja makan adalah pilihan yang terbaik dan pengiklan menegaskan bahwa produk ini(susu) dapat diminum oleh semua anggota keluarga agar stamina tubuh dapat terjaga dengan baik. Nilai dakwah juga terlihat dari iklan ini bagaimana seorang istri wajib melayani kebutuhan suami dan anak dalam hal ini memberi makan, memberi pelayanan yang baik dengan ikhlas yang dapat menyejukkan mata suami dan anak-anak.

Dari adegan kedua ini terlihat aktivitas ayah yang bersemangat dalam mencari nafkah, pengiklan seolah ingin menegaskan bahwa dampak dari mengkonsumsi susu itu dapat membuat stamina tubuh menjadi terjaga.Ayah sebagai kepala keluarga memiliki kewajiban dalam memberikan nafkah kepada istri dan anak. Begitupun juga dengan kakak tetap bersemangat bersekolah walaupun sedang berpuasa, pada saat kakak pamit kepada ibu pergi ke sekolah dengan mencium tangan ibu menandakan bukti penghormatan anak kepada ibu. Didalam Al Quran dijelaskan bagaimana kewajiban anak untuk menghormati orang tua hal ini dapat dilihat dari Surat Al Isra'(17) ayat 23 yang berbunyi :".. Dan Tuhanmu telah memerintahkan supaya kamu jangan menyembah selain Dia (Allah) dan hendaklah kamu berbuat baik kepada Ibu Bapakmu.." 
Aktivitas adik yang tetap semangat ceria di sela-sela aktivitas di sekolah seolah menggambarkan efek dari menkonsumsi susu kental manis ini. Adik yang menawarkan bantuan kepada temannya untuk membawa buku merupakan gambaran dalam perilaku Islam. Dalam Islam membantu sesama manusia adalah suatu kewajiban. Ajaran ini dapat kita lihat salah satunya melalui sabda Rasullullah barang siapa yang melapangkan satu kesusahan dunia dari seorang mukmin, maka Allah melapangkan darinya satu kesusahan di hari kiamat. 16

Begitupun juga dengan sosok Ibu tetap bersemangat mengurusi rumah tangga dengan tetap menampilkan senyum manis kepada sesamanya . Senyum adalah ibadah hal ini merupakan nilai dakwah yang diajarkan dalam Islam. Bagaimana dengan senyuman dapat menentramkan, mengakrabkan suasana. Masih dalam adegan ke dua ini bagaimana pengiklan mendesain iklan untuk menimbulkan kesan keunggulan dari produk susu kental manis ini bahwa walaupun sudah memasuki sore rasa lelah tidak terlihat, hal ini terlihat dari aktivitas kakak yang bersemangat bersepeda dengan menampilkan senyuman manis dan menyambut kedatangan ayah bersama anggota keluarga lainnya.

Adegan ketiga dalam iklan ini dimana pengiklan sengaja ingin menegaskan bahwa produk susu ini dapat digunakan untuk pelengkap minuman dalam hal ini untuk dipadukan dengan es campur. Hal ini terlihat dari sosok Ibu yang sedang sibuk mempersiapkan menu berbuka puasa yakni dengan menu es campur. Adalah suatu kewajiban bagi yang berpuasa untuk dapat berbuka puasa dengan syarat tentunya menunggu waktu magrib sehingga pada saat dalam adegan ini sang adik ingin segera mencicipi susu kental maka dilarang karena bagi siapa yang makan belum sampai pada waktu berbuka puasa maka akan membatalkan puasa dan puasa jadi sia-sia. Dipenghujun tayangan iklan muncul sebuah tulisan yang berbunyi "Awali dengan nutrisi, akhiri dengan manis" adalah penegasan dari iklan tersebut bahwa bagi umat Islam yang akan berpuasa untuk memaksimalkan nilai ibadah dengan kondisi tubuh yang fit maka tubuh harus diasupi dengan nutrisi yakni dengan cara minum susu kental manis. Dengan kondisi tubuh yang sehat maka akan memudahkan urusan ibadah lainnya baik dalam bekerja, memebantu orang dan nilai ibadah lainnya. Dengan bahasa lain pengiklan ingin mempersuasif penonton hal ini dapat diwujudkan dengan minum susu kental manis.

\footnotetext{
${ }^{16}$ www.almanhaj.or.id
} 
Hasil dari berpuasa dengan mengkonsumsi nutrisi yang baik maka maka dapat juga diinterpretasikan akan menghasilkan kesan yang manis yakni berupa kemenangan, kelegaan karena sudah dapat melawan hawa nafsu selama sehari penuh dan produk susu kenta manis seolah mampu menjawab solusi itu bahwa ibadah puasa tidak akan tergannggu karena sudah ada nutrisi yang terkandung dalam produk susu tersebut.

Pada dasarnya Islam sudah mengajarkan etika seorang muslim dalam mengatur kehidupannya agar dapat menjalani hidup dengan tenang baik cara pengaturan hubungan ibadah secara langsung kepada Allah Swt ataupun hubungan antara sesama manusia dan cara menjaga /merawat diri sendiri agar dapat memaksimalkan ibadah kepada Allah Swt. Hal ini tentunya kita dapatkan dari ajaran Al Quran dan Al Hadits yang sudah menentukan cara atau pedoman manusia dalam menjalani hidup agar mendapatkan berkah dari Allah Swt dan salah satu pesannya dapat dituangkan dalam bentuk iklan.

\section{G. Penutup}

Adapun kesimpulan yang peneliti tuangkan setelah melakukan kajian penelitian ini adalah bahwa: 1) Iklan ini menekankan bagi umat muslim yang ingin berpuasa maka harus menjaga kesehatan dengan mengkonsumsi makanan/minuman yang sehat yang mengandung nutrisi yang baik bagi tubuh manusia; 2) Terdapat nilai-nilai dakwah tergambar dari iklan ini yang muncul dari tanda-tanda verbal maupun non verbal yakni terlihat ada peran ayah selaku kepala rumah tangga yang harus bekerja untuk menafkahi keluarganya, begitupun sosok ibu selaku istri yang dapat melayani keluarga dengan sepenuh hati, anak yang harus menghomati orang tua, anak yang harus menuntut ilmu, anak yang menawarkan bantuan kepada teman, berbuka puasa menunggu waktu untuk berbuka dan dapat menampilkan senyuman tulus kepada siapapun. Hal ini semua terangkum dalam visualisasi iklan yang diteliti dan merupakan gambaran perilaku Islami.

Selain itu, rekomendasi yang dapat diberikan secara akademis adalah penelitian ini diharapkan dapat menjadi masukan bagi penelitian selanjutnya dalam kajian meneliti ilmu tanda-tanda (semiotika) yang terdapat dalam sebuah iklan untuk melihat nilai-nilai dakwah yang terkandung dalam sebuah iklan. Sedangkan secara praktis, penelitian ini diharapkan dapat menjadi masukan bagi para pengiklan untuk mendesain iklan yang lebih banyak mengangkat tema-tema dakwah sebagai sarana pembelajaran bagi masyarakat yang menonton iklan tersebut. 
Mawaizh

Jurnal Dakwah dan Pengembangan Sosial Kemanusiaan

Vol. 9, no. 1 (2018), pp. 18-39 
Mawa'izh

\section{DAFTAR PUSTAKA}

Kasmir, Kewirausahaan, Jakarta: Raja Grafindo Persada, 2010.

Kriyantono, Rachmat, Riset Komunikasi: Teknik Praktis Disertai Contoh Praktis Riset Media, Public Relations, Advertising, Komunikasi Organisasi, Komunikasi Pemasaran, Jakarta: Kencana Prenada Media Group, 2007.

Mulyana, Deddy, Ilmu Komunikasi Suatu Pengantar, Bandung: PT Remaja Rosdakarya, 2009.

SA, Enjang, Komunikasi Konseling Dari Wawancara, Seni Mendengar, sampai Soal Kepribadian, Bandung: Nuansa, 2009.

Sobur, Alex, Semiotika Komunikasi, Bandung: PT Remaja Rosdakarya, 2004.

Soemanagara, Dermawan, R. and Kennedy, E. John. Marketing Communication: Taktik \& Strategi, Jakarta: PT Bhuana Ilmu Populer, 2006.

Tunany, Ismail, Manajemen Pers Dakwah, Jakarta: Graha Guru, 2007.

Wibowo Wahyu Seto Indiwan. Semiotika Komunikasi Aplikasi Praktis bagi penelitian dan skripsi Komunikasi . Jakarta : Mitra Wacana Media, 2011.

devychandra15.blogspot.co.id/2016/05/istilah-dunia-iklan.html

https://www.almanhaj.or.ids 